\title{
Therapeutic potential of the nitrite-generated NO pathway in vascular dysfunction
}

\section{Michael Madigan* and Brian Zuckerbraun}

University of Pittsburgh, Pittsburgh, PA, USA

\section{Edited by:}

Rudolf Lucas, Medical College of Georgia, USA

\section{Reviewed by:}

Kottarappat Dileepan, The University of Kansas Medical Center, USA

Michelle L. North, Queen's University,

Canada

\section{*Correspondence:}

Michael Madigan, University of

Pittsburgh, F677 Presbyterian

Hospital, 200 Lothrop Street

Pittsburgh, PA 15213, USA

e-mail:madiganmc@upmc.edu
Nitric oxide (NO) generated through L-arginine metabolism by endothelial nitric oxide synthase (eNOS) is an important regulator of the vessel wall. Dysregulation of this system has been implicated in various pathological vascular conditions, including atherosclerosis, angiogenesis, arteriogenesis, neointimal hyperplasia, and pulmonary hypertension. The pathophysiology involves a decreased bioavailability of NO within the vessel wall by competitive utilization of L-arginine by arginase and "eNOS uncoupling." Generation of NO through reduction of nitrate and nitrite represents an alternative pathway that may be utilized to increase the bioavailability of NO within the vessel wall. We review the therapeutic potential of the nitrate/nitrite/NO pathway in vascular dysfunction.

Keywords: nitrate, nitrite, nitric oxide, pulmonary hypertension, neointimal hyperplasia, peripheral vascular disease, atherosclerosis, review

\section{INTRODUCTION}

The Nobel Prize in physiology or medicine was awarded to Drs. Furchgott, Ignarro, and Murad in 1998 for their work in identifying nitric oxide (NO), previously recognized as endothelium-derived relaxing factor, as a biologic mediator of the cardiovascular system. Since that time, NO has been extensively researched and has been linked to numerous physiological and pathological processes within the cardiovascular system. Vascular dysfunction is the root cause of a variety of important disease processes, including myocardial infarction, stroke, peripheral vascular disease, pulmonary hypertension, and wound healing. This constellation of pathology imposes a significant financial burden on the healthcare system and produces significant morbidity and mortality in those affected. The underlying pathophysiology of vascular dysfunction occurs in numerous forms, and often involves a combination of dysregulated endothelial cell NO production, increased proliferation and migration of smooth muscle cells, increased formation of intimal and medial plaques, impaired collateral vessel generation, and reduced angiogenesis.

\section{THE L-ARGININE/NITRIC OXIDE PATHWAY}

Three nitric oxide synthases (NOSs), nNOS (neuronal), iNOS (inducible), and eNOS (endothelial), were identified and initially thought to be the sole producers of NO within the cardiovascular system (1). Both nNOS and eNOS are calcium-dependent and constitutively active, while iNOS is induced under inflammatory conditions and is calcium-independent. All three isoforms metabolize $\mathrm{L}$-arginine, $\mathrm{NADPH}$, and oxygen to $\mathrm{L}$-citrulline, NADP, and NO (2) (Figure 1). L-arginine may alternatively be metabolized by arginase to L-ornithine and urea. When the supply of L-arginine is limited, metabolism via arginase may effectively reduce production of $\mathrm{NO}(3)$.

It has been suggested that the shunting of $\mathrm{L}$-arginine away from the NOS/NO pathway toward the arginase/L-ornithine pathway contributes to certain vascular pathology (4-7) (Figure 2). Expression of arginase in the vascular wall is induced under proinflammatory conditions, as well as by reactive oxygen species (ROS) and reactive nitrogen species (RNS) (8). Increased arginase activity has been associated with hypertension and coronary vascular dysfunction (9-11). Also, direct vascular injury induces a local inflammatory response. Arginase is upregulated in the vessel wall after balloon injury in the rat carotid injury model. Polyamines generated through the L-ornithine pathway form the building blocks necessary for smooth muscle cell proliferation and neointimal hyperplasia of the vessel wall (12). Peyton et al. (13) demonstrated that selective inhibitors for arginase attenuate neointimal hyperplasia in the rat carotid injury model.

Endothelial NOS is highly expressed in endothelial cells at baseline. Its metabolism of $\mathrm{L}$-arginine to $\mathrm{NO}$ is thought to be a major contributor to plasma nitrite levels, which play an important role in baseline vasodilation $(14,15)$. In addition to regulating baseline vasomotor tone, eNOS is thought to help limit platelet adhesion and thrombosis $(16,17)$. After vessel injury iNOS is upregulated in arterial smooth muscle cells and eNOS is upregulated in the endothelium resulting in increased NO production (18). Under pathological conditions, the increased NOS activity may not translate into increased NO production. Reduced NO bioavailability through eNOS "uncoupling" is a contributing factor to reduced local NO in atherosclerosis, pulmonary hypertension, and vessel injury $(7,19)$. Tetrahydrobiopterin $\left(\mathrm{BH}_{4}\right)$ is an essential cofactor for the enzymatic production of NO via NOSs (20). Uncoupling occurs under conditions of reduced $\mathrm{BH}_{4}$ availability where eNOS produces superoxide anions rather than NO $(21,22)$ (Figure 3). In addition, ROS are produced by NADPH oxidase and XOR $(23,24)$. ROS have been recognized as contributing to vascular dysfunction, through mechanisms including endothelial dysfunction, vascular smooth muscle cell growth, lipid peroxidation, and inflammation (25). An alternative source of 


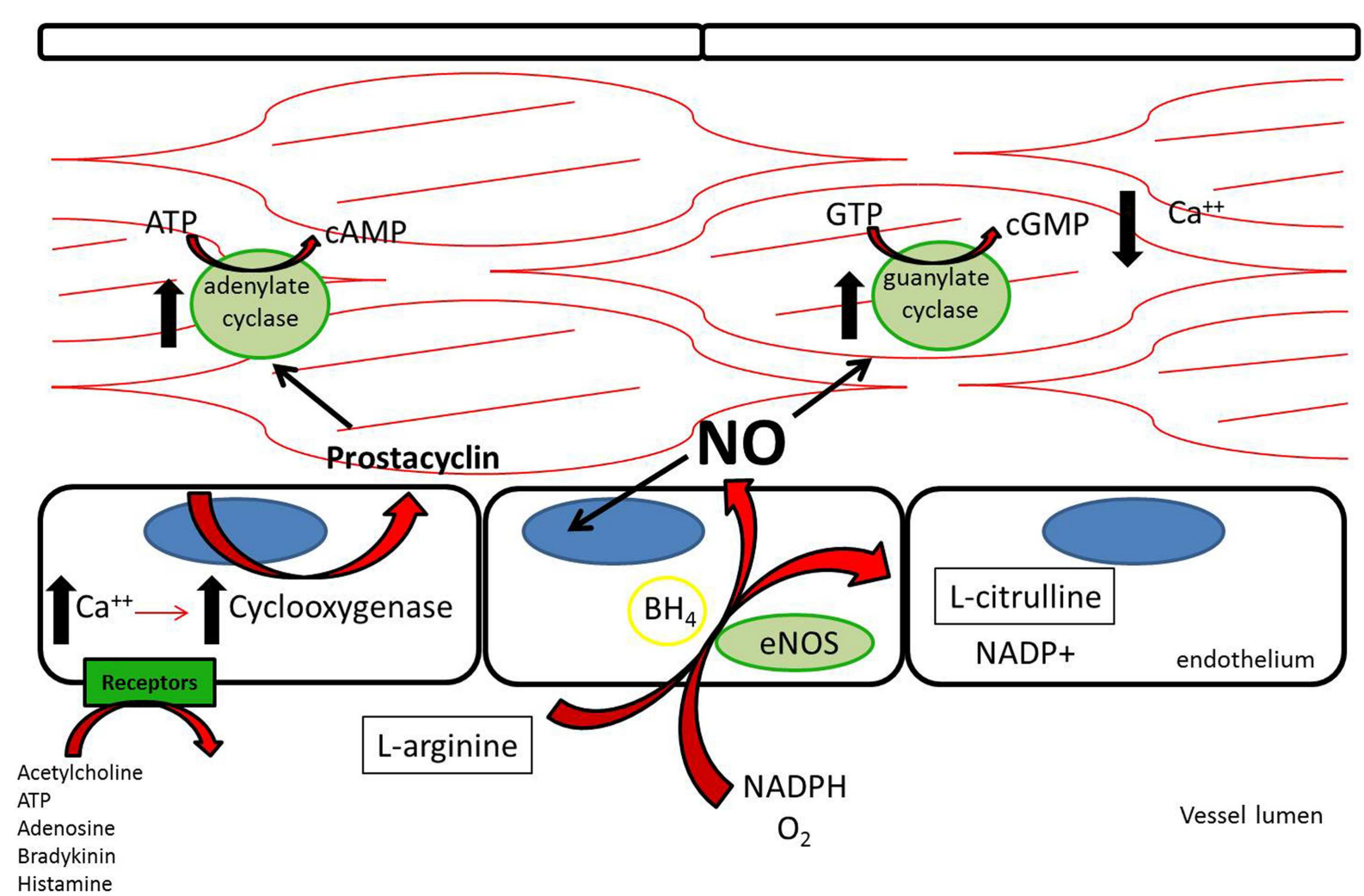

FIGURE 1 | L-Arginine is metabolized in endothelial cells via endothelial nitric oxide synthase to nitric oxide, which then acts downstream to reduce platelet adhesion, decrease leukocyte adhesion, inhibit smooth muscle proliferation and migration, and induce vasodilation. Acetylcholine, adenosine triphosphate, adenosine, bradykinin, and histamine all act on different receptors to generate downstream prostacyclin, which acts as a redundant system to induce vasodilation and platelet inhibition (112).
NO under these conditions may help restore the NO deficiency attributed to uncoupling.

\section{NITRATE/NITRITE REDUCTION TO NITRIC OXIDE}

While nitrate and nitrite were long thought of as stable endproducts of NO metabolism, recent evidence supports nitrate and nitrite as potential sources of NO under appropriate conditions (12, 26-29) (Figure 4). As opposed to the NOS enzymes, which require oxygen as a substrate for NO generation, nitritegenerated production of $\mathrm{NO}$ has been shown to occur more readily under acidic and hypoxic conditions (113, 30-32). Nitrate/nitrite reduction has been shown to occur via deoxygenated hemoglobin, myoglobin, enzymatic, and non-enzymatic means (33-37). A class of molybdenum-containing enzymes, including xanthine oxidoreductase (XOR), aldehyde oxidase (AOX), and sulfite oxidase (SUOX), have been identified as enzymes that may facilitate the reduction of nitrate and nitrite to NO at the molybdenumcontaining site (38). We and others have shown that XOR in particular is present within the vessel wall and tissue and contributes to NO production in intimal hyperplasia, pulmonary hypertension, and ischemia-reperfusion $(12,26,39)$.

While L-arginine is a significant contributor to plasma nitrite production through the L-arginine/NOS/NO/nitrite pathway, plasma nitrite levels are also dependent on oral consumption of nitrate and nitrite (40). The Mediterranean diet, which has been associated with a lower risk of atherosclerosis and coronary artery disease, adds credence to the importance of oral nitrate/nitrite-derived NO in vascular biology $(41,42)$. The Mediterranean diet, known for its high content of nitrate-rich leafy green vegetables, has also been found to lower the blood pressure of healthy volunteers $(40,43)$. The nitrate/nitrite/NO pathway through oral ingestion is thought to rely on a symbiotic relationship with natural oral flora. Nitrate is concentrated within the salivary glands and salivary bacteria reduce nitrate to nitrite in the oral cavity (44). Once nitrite reaches the stomach, it is reduced to NO by protonation due to the stomach's low $\mathrm{pH}$ (45). NO then may act locally by enhancing mucosal blood flow to the stomach (45-47). Nitrite is also absorbed in the stomach where it enters the blood stream (48). Due to its relative stability, nitrite then has the ability to circulate to other areas in the body and undergo reduction to NO under acidic and hypoxic conditions (33). Acting in this way, circulating nitrite has been described as a "storage pool" for NO within the body (27).

Historically, there has been concern that oral nitrate/nitrite consumption may increase the risk of some cancers, including esophageal, stomach, and colon cancer. Some epidemiological studies have suggested that high oral intake of nitrate/nitrite correlates with increased risk of gastrointestinal malignancy, though 


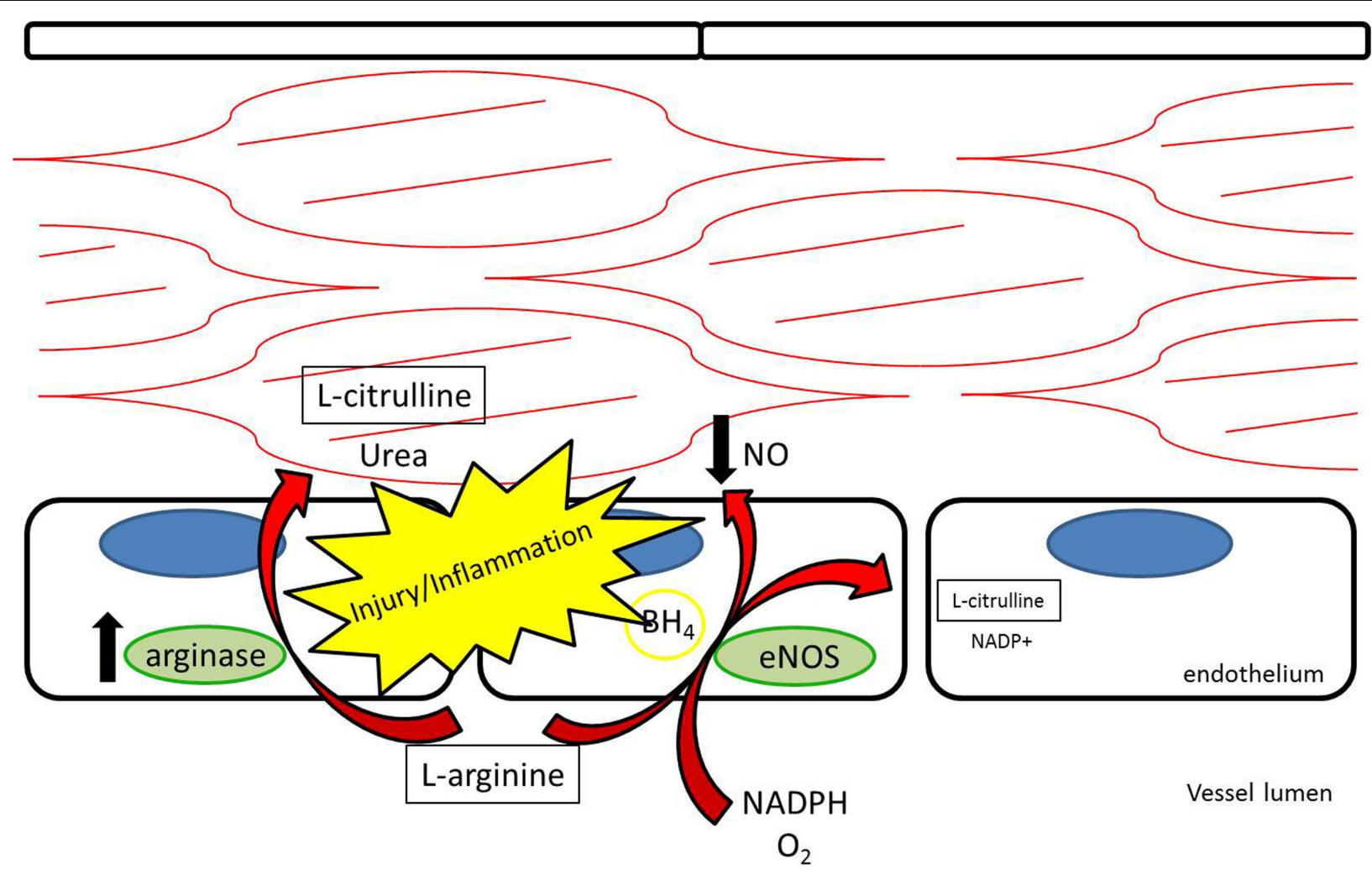

FIGURE 2 | L-arginine may be competitively metabolized by arginase to L-citrulline and urea, reducing production of nitric oxide and contributing to vascular dysfunction.

accuracy in calculating dietary exposure is difficult (49). Nitrosylation of secondary amines via nitrite occurs readily under acidic conditions, such as in the stomach, resulting in N-nitrosamines. Around $300 \mathrm{~N}$-nitrosamines have been identified as carcinogenic (50). The National Toxicology Program (51) of the US Department of Health and Human Services found no evidence of carcinogenic activity in mice and rats after 2 years of exposure to oral sodium nitrite. The International Agency for Research on Cancer (52), a division of the World Health Organization, evaluated the evidence concerning dietary consumption of nitrate/nitrite and carcinogenicity in their monographs. The IARC concluded that inadequate evidence exists in humans and experimental animals for the carcinogenicity of nitrate in food and drinking water and limited evidence exists to suggest carcinogenicity of nitrite in food and drinking water (52). The IARC did, however, recognize that sufficient evidence exists in experimental animals to suggest the carcinogenicity of nitrite in combination with amines or amides and that nitrite in food is correlated with stomach cancer (52). Ongoing research will help elucidate the specific conditions in which $N$-nitrosamines may be carcinogenic in humans.

Multiple investigations have demonstrated that the nitrate/nitrite/NO pathway has vasoactive properties in the systemic and pulmonary circulations. Infusion of nitrite into the forearm brachial artery increased local blood flow and decreased blood pressure at rest and during exercise in humans (33). The infusion correlated with an increase in erythrocyte iron-nitrosylated hemoglobin, suggesting that hemoglobin may play a role in transporting NO through the bloodstream. Dietary supplementation has the potential to achieve similar results systemically. Larsen et al. (43) used a 3-day dietary supplementation of nitrate $(0.1 \mathrm{mmol} / \mathrm{kg}$ body weight) in healthy volunteers and showed an increase in plasma nitrate $(178 \pm 51$ vs. $26 \pm 11 \mu \mathrm{M})$ and nitrite $(219 \pm 105$ vs. $138 \pm 38 \mu \mathrm{M})$. After 3 days, the volunteers also had a decrease in diastolic and mean blood pressure by $3.7 \mathrm{mmHg}$ and $3.2 \mathrm{mmHg}$, respectively. In a similar study using a Japanese diet high in nitrate, Sobko et al. (53) demonstrated an increase in both salivary and plasma levels of nitrate and nitrite. These volunteers had an average $4.5 \mathrm{mmHg}$ drop in diastolic blood pressure after 10 days. Dietary nitrate may also effect the pulmonary circulation. In mice exposed to hypoxia to induce pulmonary hypertension, dietary nitrate reduced vascular remodeling and right ventricular hypertrophy through pulmonary vasodilation (26). Inhaled nitrite is an alternative delivery method that has the potential to induce pulmonary vasodilation while minimizing systemic effects. Nebulized sodium nitrite reduced hypoxia-induced pulmonary hypertension in lambs by $65 \%$ with no drop in systemic blood pressure (54).

\section{NITRIC OXIDE AND THE VESSEL RESPONSE TO INJURY}

Nitric oxide has been shown to serve many vasoprotective properties that occur after vessel injury, including reduction of platelet deposition, decrease in leukocyte adhesion, inhibition of smooth 


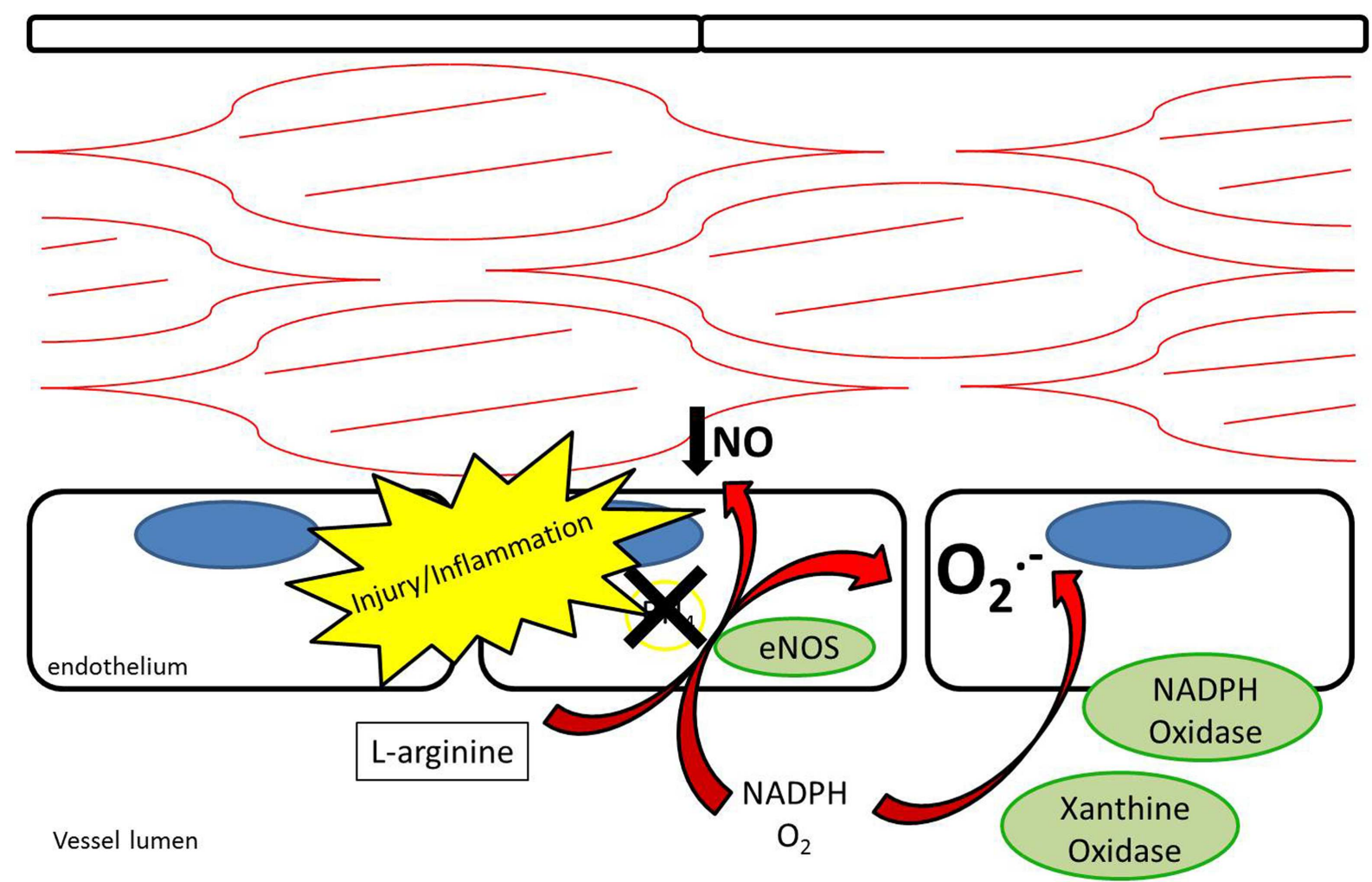

FIGURE 3 | Endothelial nitric oxide synthase uncoupling results in reduced production of nitric oxide as well as production of superoxide anions. NADPH oxidase and xanthine oxidase also contribute to production of superoxide anions.

muscle cell proliferation and migration, and induction of vasodilation (55). One of the initial responses to endothelial disruption is platelet activation and plug formation. NO and NOS expression are associated with decreased platelet adhesion at the vessel wall $(56,57)$. NO has been shown to be a potent inhibitor of platelet adhesion, reducing thrombosis within the vessel lumen $(58,59)$. NO mediates platelet adhesion though upregulation of plateletsoluble guanylate cyclase production of cyclic GMP. Nitrate and nitrite-supplemented diets increase bleeding times in mice, and there is an inverse relationship between blood nitrate/nitrite levels and platelet function (60). After platelet deposition, neutrophils and macrophages begin to infiltrate the vessel wall. NO inhibits leukocyte adhesion and the subsequent vessel inflammatory response after injury $(61,62)$. Once the inflammatory response sets in, smooth muscle cells infiltrate the medial layer and begin proliferating. The resulting thickened medial layer narrows the lumen and stiffens the vessel wall. NO acts to reduce the smooth muscle cell response in multiple ways. NO was first recognized as the substance responsible for calcium-dependent relaxation of the vascular smooth muscle cells (63). NO upregulates soluble guanylyl cyclase within cells and leads to increased cyclic GMP. Cyclic GMP then interacts with protein kinases to lower cytoplasmic calcium, which results in vasodilation (64). Also, it has been shown in culture that NO reversibly arrests the cell cycle of vascular smooth muscle cells (65). NO inhibits smooth muscle proliferation within the vessel wall via a p21 dependent mechanism
(66-68). Overall, NO reduces smooth muscle cell migration and proliferation, which can lead to atherosclerosis and neointimal hyperplasia (69).

\section{NITRIC OXIDE AND ATHEROSCLEROSIS}

Atherosclerosis resulting in coronary artery disease and stroke are the leading causes of death in the developed world (70). Atherosclerotic plaques are formed when the endothelial layer is damaged and cholesterol accumulates within the vessel wall. Macrophages are recruited to the site of injury, form foam cells, and release cytokines leading to an inflammatory response (71). Smooth muscle cells then migrate and proliferate within the vessel wall, eventually leading to an organized plaque (72). Repeated vessel wall injury causes thrombosis and narrowing of the lumen, which leads to ischemia of the tissue bed supplied by the vessels.

While atherosclerosis is a multifactorial process, dysregulation of the arginine/NOS balance contributes to the development of atherosclerotic disease (73). For instance, iNOS inhibition in the apolipoprotein E knockout mouse model for atherosclerosis accelerates the progression of atherosclerotic disease in these mice (74). Restoring the balance of NO production at multiple points along the pathway reduces formation of atherosclerotic plaques. L-Arginine supplementation has been shown to improve vasodilation in cholesterol-fed rabbits and monkeys and reduce the progression of atherosclerosis (75-77). Also, exogenous expression of iNOS in the arteries reduces the injury response 


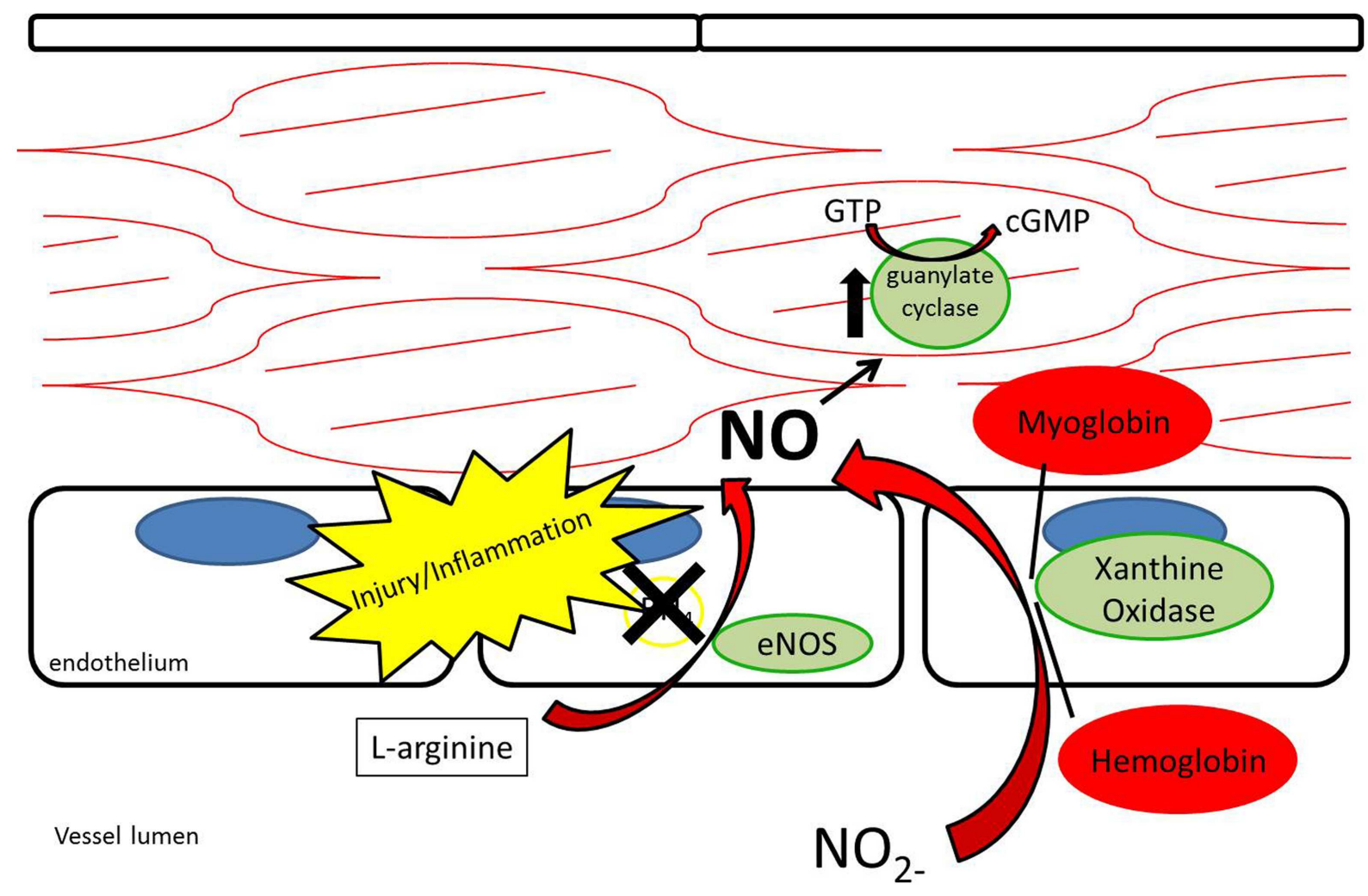

FIGURE 4 | Nitrite reduction by xanthine oxidoreductase, myoglobin, hemoglobin, and protonation results in nitric oxide production, especially under conditions of hypoxia and acidemia.

and atherosclerotic development (78). Furthermore, supplemental oral nitrite has also been shown to be beneficial in reducing vessel inflammation and endothelial dysfunction in mice treated with a high cholesterol diet (79).

NOS enzyme dysregulation results not only in reduced NO availability, but also increased superoxide anions and arginase activity, both of which are detrimental to maintaining healthy vasculature $(80,81)$. Oxidized low-density lipoproteins (OxLDL) caused by the interaction between LDL and superoxide anions correlate with atherosclerotic disease (82). OxLDL is taken up by macrophages, which forms foam cells on the vessel wall (73). OxLDLs also have been shown to induce apoptosis of endothelial cells and impair endothelium-dependent arterial relaxation within atherosclerotic vessels (83-85). On the contrary, NO has been shown to inhibit apoptosis in endothelial progenitor cells caused by oxidized low-density lipid proteins (86).

\section{NITRIC OXIDE AND PERIPHERAL ARTERIAL DISEASE}

Nitric oxide is an important regulator of the tissue response to peripheral arterial disease and lower extremity ischemia, specifically enhancing arteriogenesis, angiogenesis, and progenitor cell migration $(4,87,88)$. Arteriogenesis is a recognized phenomenon that involves the enlargement of pre-existing collaterals as a result of increased sheer stress, often in response to stenotic or occluded primary vessels. Angiogenesis, on the other hand, is induced by vascular endothelial growth factor and occurs in response to tissue ischemia (89). As a result, new capillaries are formed (90). Endothelial NOS knockout mice show impaired arteriogenesis, angiogenesis, and pericyte recruitment after femoral artery ligation. All three processes are reversed in this model by intramuscular injection of adenovirus encoding eNOS, suggesting that NO is an important mediator of these processes during lower extremity ischemia (91).

In addition to eNOS-generated NO, the nitrite/NO pathway is functional in the peripheral vasculature. Intraperitoneal (IP) nitrite injections have been shown to improve tissue perfusion through increased collateral vessel development in the murine femoral ligation model of acute limb ischemia (92). IP delivered nitrite also improved angiogenesis and cutaneous flow in rat ischemic myocutaneous flaps, reducing tissue death via a nitrite/NO pathway (93). Nitrite therapy, delivered even in a delayed fashion, augments arteriogenesis in the mouse hindlimb ischemia model (94). Additionally, dietary nitrate supplementation increased capillary and bonemarrow derived progenitor cell density in ischemic hind-limbs, a process that was inhibited with antiseptic mouthwash (95). Antiseptic mouthwash reduces the concentration of the oral bacteria responsible for nitrate reduction to nitrite, thus disrupting the nitrate-nitrite-NO pathway (96). In a small study of healthy volunteers, antiseptic mouthwash increased systolic and diastolic blood pressure by $2-3.5 \mathrm{~mm} \mathrm{Hg}$ during a 7 day course (97). 


\section{NITRIC OXIDE AND NEOINTIMAL HYPERPLASIA}

Neointimal hyperplasia is an exaggerated inflammatory healing response after vascular injury. Of particular interest is neointimal hyperplasia after balloon angioplasty and vascular stent deployment, since this may limit therapeutic success. After vessel injury, platelets adhere to the vessel wall denuded of endothelium and generate a cascade of events leading to leukocyte chemotaxis, extracellular matrix modification, endothelial cell apoptosis, and vascular smooth muscle cell migration and proliferation (55). NO has been shown to limit neointimal hyperplasia through multiple levels. Similar to atherosclerosis, NO modulates neointimal hyperplasia through inhibition of platelet aggregation, decreased leukocyte chemotaxis, and reduced vascular smooth muscle cell proliferation while stimulating that of endothelial cells $(57-59,62,65,67,68,98,99)$. The effects of NO may be limited by L-arginine shunting away from eNOS to arginase under pathological conditions. Arginase metabolism of L-arginine leads to the production of polyamines utilized in cell proliferation, and the expression of arginase I is increased in the proliferation of rat aortic smooth muscle cells (100). It has been demonstrated that arginase I activity is increased within the vessel wall after carotid balloon injury in rats, and that inhibition of arginase decreases neointimal hyperplasia in that model (13). Furthermore, Alef et al. (5) demonstrated that nitritesupplemented drinking water acts to reduce intimal hyperplasia in the rat carotid injury model, and that this NO is generated through XOR.

\section{NITRIC OXIDE AND PULMONARY ARTERIAL HYPERTENSION}

Pulmonary hypertension is a vascular disease characterized by hypoxia, pulmonary vasoconstriction, increased vascular resistance, vessel remodeling, thrombosis, and right ventricular strain $(7,101)$. Multiple etiologies likely contribute to the development of pulmonary hypertension, but all involve increased vascular resistance as a prominent factor. NO, an important regulator of pulmonary vascular resistance, acts as a vasorelaxing agent within the pulmonary arterial system as well as a protective agent against smooth muscle cell proliferation within the vascular wall (102, 103). It has been proposed that NO may act as a "hypoxic buffer" that leads to vasodilation under hypoxic conditions, such as occurs

\section{REFERENCES}

1. Bryan NS, Bian K, Murad F. Discovery of the nitric oxide signaling pathway and targets for drug development. Front Biosci (2009) 14:1-18.

2. Alderton WK, Cooper CE, Knowles RG. Nitric oxide synthases: structure, function, and inhibition. Biochem J (2001) 357(Pt 3):593-615. doi:10.1042/ 0264-6021:3570593

3. Li H, Meininger CJ, Hawker JR Jr, Haynes TE, Kepka-Lenhart D, Mistry SK, et al. Regulatory role of arginase I and II in nitric oxide, polyamine, and proline synthesis in endothelial cells. Am J Physiol Endocrinol Metab (2001) 280:E75-82.
4. Allen JD, Giordano T, Kevil CG. Nitrite and nitric oxide metabolism in peripheral artery disease. Nitric Oxide (2012) 26:217-22. doi:10.1016/j.niox.2012.03.003

5. Alef MJ, Vallabhaneni R, Carchman E, Morris SMJr, Shiva S, Wang Y, et al. Nitritegenerated NO circumvents dysregulated arginine/NOS signaling to protect against intimal hyperplasia in SpragueDawley rats. J Clin Invest (2011) 121(4):1646-56. doi:10.1172/ JCI44079

6. Lundberg JO, Gladwin MT, Ahluwalia A, Benjamin N, Bryan NS, Butler A, et al. Nitrate and nitrite in biology, nutrition and therapeutics. Nat

in pulmonary hypertension $(104,105)$. This theory proposes that increased nitrite reduction to NO helps to counterbalance the hypoxic pulmonary vasoconstriction by generating a vasodilatory signal. Inhaled nitrite is being utilized in pulmonary hypertension as a direct means of delivering NO to the pulmonary vasculature (106). Also, dietary nitrite in mice increases pulmonary dilation, inhibits vascular remodeling, and decreases right ventricular hypertrophy. This effect was reduced in eNOS knockout mice and after allopurinol treatment (26). In a rat model of pulmonary hypertension, it has been shown that inhaled nitrite reverses the effect of hypoxia-induced pulmonary hypertension through creation of NO via XOR (103).

Investigation into the $\mathrm{L}$-arginine/nitrite/NO pathway in pulmonary hypertension has led to conflicting results as far as the importance of this system. Variation in eNOS expression has been observed in human tissue studies, despite consistently elevated eNOS in animal studies (107-109). Inducible NOS has also been shown to be increased in some studies (110). The upregulation of the NOSs may be a compensatory response to upregulated arginase activity. Like other vascular disorders, arginase activity has been shown to be increased in pulmonary hypertension (111). Increased arginase may have a dual role of decreasing $\mathrm{L}$-arginine metabolism to $\mathrm{NO}$ as well as polyamine-induced increases in smooth muscle cell proliferation within the vessel walls (7).

\section{SUMMARY}

Nitric oxide is an important regulator of vascular function. An imbalance in NO production in relation to ROSs, RNSs, and other inflammatory mediators is associated with many forms of vascular dysfunction, including atherosclerosis, peripheral arterial disease, neointimal hyperplasia, and pulmonary hypertension. The recently discovered nitrate/nitrite/NO pathway is an alternative means of delivering $\mathrm{NO}$ to areas of deficiency. In order to harness this pathway as a therapeutic, efficient delivery to the affected tissues must be accomplished. Because of its relatively stable nature and the recognition that nitrate, nitrite, hemoglobin, and myoglobin within the blood act as a 'storage pool' of NO, a variety of potential delivery options to areas of vascular dysfunction exist, including dietary supplementation, inhalation, and direct intravenous infusion.

Chem Biol (2009) 5:865-9. doi:10.1038/nchembio.260

7. Zuckerbraun BS, George P, Glawin MT. Nitrite in pulmonary arterial hypertension: therapeutic avenues in the setting of dysregulated arginine/nitric oxide synthase signaling. Cardiovasc Res (2011) 89(3):542-52. doi:10.1093/cvr/cvq370

8. Pernow J, Jung C. Arginase as a potential target in the treatment of cardiovascular disease: reversal of arginine steal? Cardiovasc Res (2013) 98(3):334-43. doi:10.1093/cvr/cvt036

9. Jung $\mathrm{C}$, Gonon AT, Sjöquist PO, Lundberg JO, Pernow J. Arginase inhibition mediates cardioprotection during ischemia-reperfusion. Cardiovasc Res (2010) 85:147-54. doi:10.1093/cvr/cvp303

10. Zhang C, Hein TW, Wang W, Miller MW, Fossum TW, McDonald MM, et al. Upregulation of vascular arginase in hypertension decreases nitric oxide-mediated dilation of coronary arterioles. Hypertension (2004) 44:935-43. doi:10.1161/ 01.HYP.0000146907.82869.f2

11. Grönros J, Jung C, Lundberg JO, Cerrato R, Ostenson CG, Pernow J. Arginase inhibition restores in vivo coronary microvascular function in type 2 diabetic rats. Am J Physiol Heart Circ Physiol (2011) 300:H1174-81. doi:10.1152/ ajpheart.00560.2010 
12. Alef MJ, Tzeng E, Zuckerbraun BS. Nitric oxide and nitrite-based therapeutic opportunities in intimal hyperplasia. Nitric Oxide (2012) 26:285-94. doi:10.1016/ j.niox.2012.03.014

13. Peyton KJ, Ensenat D, Azam MA, Keswani AN, Kannan S, Liu XM, et al. Arginase promotes neointima formation in rat injured carotid arteries. Arterioscler Thromb Vasc Biol (2009) 29:488-94. doi:10.1161/ ATVBAHA.108.183392

14. Kleinbongard P, Dejam A, Lauer T, Rassaf T, Schindler A, Picker $\mathrm{O}$, et al. Plasma nitrite reflects constitutive nitric oxide synthase activity in mammals. Free Radic Biol Med (2003) 35(7):790-6. doi:10.1016/S08915849(03)00406-4

15. Rhodes P, Leone AM, Francis PL, Struthers AD, Moncada $S$, Rhodes PM [corrected to Rhodes P]. The L-arginine:nitric oxide pathway is the major source of plasma nitrite in fasted humans. Biochem Biophys Res Commun (1995) 209(2):590-6. doi:10.1006/bbrc.1995.1541

16. Huang PL, Huang Z, Mashimo H, Bloch KD, Moskowitz MA, Bevan JA, et al. Hypertension in mice lacking the gene for endothelial nitric oxide synthase. Nature (1995) 377(6546):23942. doi:10.1038/377239a0

17. Golino $\mathrm{P}$, Cappelli-Bigazzi $\mathrm{M}$, Ambrosio G, Ragni M, Russolillo E, Condorelli $\mathrm{M}$, et al. Endothelium-derived relaxing factor modulates platelet aggregation in an in vivo model of recurrent platelet activation. Circ Res (1992) 71(6):1447-56. doi:10.1161/01.RES.71.6.1447

18. Hansson GK, Geng YJ, Holm J, Hårdhammar P, Wennmalm A, Jennische E. Arterial smooth muscle cells express nitric oxide synthase in response to endothelial injury. $J$ Exp Med (1994) 180(2):733-8. doi:10.1084/jem.180.2.733

19. Keitadisorn R, Juni RP, Moens AL. Tackling endothelial dysfunction by modulating NOS uncoupling: new insights into its pathogenesis and therapeutic possibilities. Am J Physiol Endocrinol Metab (2012) 302:E481-95. doi:10.1152/ajpendo.00540.2011

20. Katusic ZS. Vascular endothelial dysfunction: does tetrahydrobiopterin play a role? $A m J$
Physiol Heart Circ Physiol (2001) 281(3):H981-6.

21. Khoo JP, Zhao L, Alp NJ, Bendall JK, Nicoli T, Rockett $\mathrm{K}$, et al. Pivotal role for endothelial tetrahydrobiopterin in pulmonary hypertension. Circulation (2005) 111:2126-33. doi:10.1161/01.CIR.0000162470. 26840.89

22. Stuehr D, Pou S, Rosen GM. Oxygen reduction by nitric oxide synthases. $J$ Biol Chem (2001) 276:14533-6. doi:10.1074/jbc.R100011200

23. Jacobson A, Yan C, Gao Q, Rincon-Skinner $\mathrm{T}$, Rivera A, Edwards J, et al. Aging enhances pressure-induced arterial superoxide formation. Am J Physiol Heart Circ Physiol (2007) 293:H1344-50. doi:10.1152/ajpheart.00413.2007

24. Tabima DM, Frizzell S, Gladwin MT. Reactive oxygen and nitrogen species in pulmonary hypertension. Free Radic Biol Med (2012) 52(9):1970-86. doi:10.1016/ j.freeradbiomed.2012.02.041

25. Touyz RM. Reactive oxygen species, vascular oxidative stress, and redox signaling in hypertension. Hypertension (2004) 44:248-52. doi:10.1161/ 01.HYP.0000138070.47616.9d

26. Baliga RS, Milsom AB, Ghosh SM, Trinder SL, Macallister RJ, Ahluwalia A, et al. Dietary nitrate ameliorates pulmonary hypertension: cytoprotective role for endothelial nitric oxide synthase and xanthine oxidoreductase. Circulation (2012) 125(23):2922-32. doi:10.1161/ CIRCULATIONAHA.112.100586

27. Dejam A, Hunter CJ, Schechter AN, Gladwin M. Emerging role of nitrite in human biology. Blood Cells Mol Dis (2004) 32(3):423-9. doi:10.1016/j.bcmd.2004.02.002

28. Gladwin MT, Raat NJ, Shiva S, Dezfulian C, Hogg N, KimShapiro DB, et al. Nitrite as a vascular endocrine nitric oxide reservoir that contributes to hypoxic signaling, cytoprotection, and vasodilation. Am J Physiol Heart Circ Physiol (2006) 291(5):H2026-35. doi:10.1152/ajpheart.00407.2006

29. Murata I, Nozaki R, Ooi $\mathrm{K}$, Ohtake K, Kimura S, Ueda $\mathrm{H}$, et al. Nitrite reduces ischemia/reperfusion-induced muscle damage and improves survival rates in rat crush injury model. J Trauma Acute Care Surg (2012) 72(6):1548-54. doi:10.1097/ TA.0b013e31824a76b5

30. Huang Z, Shiva S, Kim-Shapiro DB, Patel RP, Ringwood LA, Irby $\mathrm{CE}$, et al. Enzymatic function of hemoglobin as a nitrite reductase that produces $\mathrm{NO}$ under allosteric control. J Clin Invest (2005) 115(8):2099-107. doi:10.1172/JCI24650

31. Li H, Cui H, Kundu TK, Alzawahra W, Zweier JL. Nitric oxide production from nitrite occurs primarily in tissues not in the blood. J Biol Chem (2008) 283:17855-63. doi:10.1074/jbc.M801785200

32. Godber BL, Doel JJ, Sapkota GP, Blake DR, Stevens CR, Eisenthal R, et al. Reduction of nitrite to nitric oxide catalyzed by xanthine oxidoreductase. J Biol Chem (2000) 275(11):7757-63. doi:10.1074/ jbc.275.11.7757

33. Cosby K, Partovi KS, Crawford $\mathrm{JH}$, Patel RP, Reiter CD, Martyr S, et al. Nitrite reduction to nitric oxide by deoxyhemoglobin vasodilates the human circulation. Nat Med (2003) 9(12):1498-505. doi:10.1038/nm954

34. Nagabubu E, Ramasamy S, Abernethy DR, Rifkind JM. Active nitric oxide produced in the red cell under hypoxic conditions by deoxyhemoglobinmediated nitrite reduction. J Biol Chem (2003) 278(47):46349-56. doi:10.1074/jbc.M307572200

35. Shiva S, Huang Z, Grubina R, Sun J, Ringwood LA, MacArthur PH et al. Deoxymyoglobin is a nitrite reductase that generates nitric oxide and regulates mitochondrial respiration. Circ Res (2007) 100(5):654-61.

36. Rassaf T, Flögel U, Drexhage C, Hendgen-Cotta U, Kelm M, Schrader J. Nitrite reductase function of deoxymyoglobin: oxygen sensor and regulator of cardiac energetics and function. Circ Res (2007) 100(12):1749-54. doi:10.1161/ CIRCRESAHA.107.152488

37. Zweier JL, Samouilov A, Kuppusamy P. Non-enzymatic nitric oxide synthesis in biological systems. Biochem Biophys Acta (1999) 1411(23):250-62. doi:10.1016/S00052728(99)00018-3

38. Maia LB, Moura JJG. Nitrite reduction by xanthine oxidase family enzymes: a new class of nitrite reductases. $J$ Biol Inorg Chem (2011) 16:443-60. doi:10.1007/s00775-010-0741-z

39. Tripatara P, Patel NS, Webb A, Rathod K, Lecomte FM, Mazzon E, et al. Nitrite-derived nitric oxide protects the rat kidney against ischemia/reperfusion injury in vivo: role for xanthine oxidoreductase. $J \quad A m$ Soc Nephrol (2007) 18:570-80. doi:10.1681/ASN.2006050450

40. Lundberg JO, Feelisch M, Björne $\mathrm{H}$, Jansson $\mathrm{EA}$, Weitzberg E. Cardioprotective effects of vegetables: is nitrite the answer? Nitric Oxide (2006) 15(4):359-62. doi:10.1016/j.niox.2006.01.013

41. Lidder S, Webb AJ. Vascular effects of dietary nitrate (as found in green leafy vegetables and beetroot) via the nitrate-nitrite-nitric oxide pathway. Br J Clin Pharmacol (2012) 75(3):677-96.

42. de Lorgeril M, Renaud S, Mamelle N, Salen P, Martin JL, Monjaud I, et al. Mediterranean alpha-linolenic acid-rich diet in secondary prevention of coronary heart disease. Lancet (1994) 343(8911):1454-9. doi:10.1016/ S0140-6736(94)92580-1

43. Larsen FJ, Ekblom B, Sahlin $\mathrm{K}$, et al. Effects of dietary nitrate on blood pressure in healthy volunteers. $N$ Engl $J$ Med (2006) 355(26):2792-3. doi:10.1056/NEJMc062800

44. Duncan C, Dougall H, Johnston P, Green S, Brogan R, Leifert $\mathrm{C}$, et al. Chemical generation of nitric oxide in the mouth from the enterosalivary circulation of dietary nitrite. Nat Med (1995) 1(6):546-51. doi:10.1038/nm0695-546

45. Benjamin N, O'Driscoll F, Dougall H, Duncan C, Smith $\mathrm{L}$, Golden M, et al. Stomach NO synthesis. Nature (1994) 368:502. doi:10.1038/ 368502a0

46. Björne HH, Petersson J, Phillipson $\mathrm{M}$, Weitzberg E, Holm L, Lundberg JO. Nitrite in saliva increases gastric mucosal blood flow and mucus thickness. J Clin Invest (2004) 113(1):106-14. doi:10.1172/ JCI19019E1

47. McKnight GM, Smith LM, Drummond RS, Duncan CW, Golden M, Benjamin N. Chemical synthesis of nitric oxide in the stomach from dietary 
nitrate in humans. Gut (1997) 40(2):211-4.

48. Miyoshi M, Kasahara E, Park AM, Hiramoto K, Minamiyama Y, Takemura S, et al. Dietary nitrate inhibits stress-induced gastric mucosal injury in the rat. Free Radic Res (2003) 37(1):85-90. doi:10.1080/ 1071576021000086632

49. Milkowski A, Garg HK, Coughlin JR, Bryan NS. Nutritional epidemiology in the context of nitric oxide biology: a risk-benefit evaluation for dietary nitrite and nitrate. Nitric Oxide (2010) 22:110-9. doi:10.1016/j.niox.2009.08.004

50. Hecht SS. Approaches to cancer prevention based on an understanding of N-nitrosamine carcinogenesis. Proc Soc Exp Biol Med (1997) 216(2):181-91.

51. National Toxicology Program. Toxicology and carcinogenesis of sodium nitrite (CAS NO. 7632-00-0) in $\mathrm{F} 344 / \mathrm{N}$ rats and B6C3F1 mice (drinking water studies). Natl Toxicol Program Tech Rep Ser (2001) 495:7-273.

52. International Agency for Research on Cancer. Monographs on the evaluation of carcinogenic risks to humans: ingested nitrates and nitrites. IARC (2006). Available at: http://monographs.iarc.fr/ENG/ Monographs/vol94/mono94-6. pdf

53. Sobko T, Marcus C, Govoni M, Kamiya S. Dietary nitrate in Japanese traditional foods lowers diastolic blood pressure in healthy volunteers. Nitric Oxide (2010) 22(2):136-40. doi:10.1016/j.niox.2009.10.007

54. Hunter CJ, Dejam A, Blood AB, Shields H, Kim-Shapiro DB, Machado RF, et al. Inhaled nebulized nitrite is a hypoxia-sensitive NOdependent selective pulmonary vasodilator. Nat Med (2004) 10:1122-7. doi:10.1038/nm1109

55. Ahanchi SS, Tsihlis ND, Kibbe MR. The role of nitric oxide in the pathophysiology of intimal hyperplasia. J Vasc Surg (2007) 45(Suppl A):A64-73. doi:10.1016/j.jvs.2007.02.027

56. Radomski MW, Palmer RM, Moncada S. Endogenous nitric oxide inhibits human platelet adhesion to vascular endothelium. Lancet (1987) 2(8567):1057-8. doi:10.1016/ S0140-6736(87)91481-4
57. Yan ZQ, Yokota T, Zhang W, Hansson GK. Expression of inducible nitric oxide synthase inhibits platelet adhesion and restores blood flow in the injured artery. Circ Res (1996) 79:38-44. doi:10.1161/01.RES.79.1.38

58. de Graaf JC, Banga JD, Moncada S, Palmer RM, de Groot PG, Sixma JJ. Nitric oxide functions as an inhibitor of platelet adhesion under flow conditions. Circulation (1992) 85(6):2284-90. doi:10.1161/ 01.CIR.85.6.2284

59. Radomski MW, Palmer RM, Moncada S. An L-arginine/nitric oxide pathway present in human platelets regulates aggregation. Proc Natl Acad Sci U S A (1990) 87(13):5193-7. doi:10.1073/pnas.87.13.5193

60. Park JW, Piknova B, Huang PL, Noguchi CT, Schechter AN. Effect of blood nitrite and nitrate levels on murine platelet function. PLOS ONE (2013) 8(2):e55699. doi:10.1371/ journal.pone.0055699

61. Hickey MJ, Sharkey KA, Sihota EG, Reinhardt PH, Macmicking JD, Nathan C, et al. Inducible nitric oxide synthase-deficient mice have enhanced leukocyteendothelium interactions in endotoxemia. FASEB J (1997) 11:955-64.

62. Kubes P, Suzuki M, Granger DN. Nitric oxide: an endogenous modulator of leukocyte adhesion. Proc Natl Acad Sci $U$ S A (1991) 88:4651-5. doi:10.1073/pnas.88.11.4651

63. Palmer RMJ, Ferrige AG, Moncada S. Nitric oxide release accounts for the biological activity of endotheliumderived relaxing factor. Nature (1987) 327:524-6. doi:10.1038/327524a0

64. Moncada S, Higgs EA. Molecular mechanisms and therapeutic strategies related to nitric oxide. FASEB J (1995) 9:1319-30.

65. Sarkar R, Gordon D, Stanley JC, Webb RC. Cell cycle effects of nitric oxide on vascular smooth muscle cells. Am J Physiol (1997) 272:H1810-8.

66. Ishida A, Sasaguri T, Kosaka C, Nojima H, Ogata J. Induction of the cyclindependent kinase inhibitor p21(Sdi1/Cip1/Waf1) by nitric oxide-generating vasodilator in vascular smooth muscle cells. J Biol Chem (1997) 272:10050-7. doi:10.1074/jbc.272.15.10050
67. Kibbe MR, Li J, Nie S, et al. Inducible nitric oxide synthase (iNOS) expression upregulates p21 and inhibits vascular smooth muscle cell proliferation through p42/44 mitogen-activated protein kinase activation and independent of p53 and cyclic guanosine monophosphate. J Vasc Surg (2000) 31:1214-28. doi:10.1067/mva.2000.105006

68. Tanner FC, Meier P, Greutert $H$, Champion C, Nabel EG, Lüscher TF. Nitric oxide modulates expression of cell cycle regulatory proteins: a cytostatic strategy for inhibition of human vascular smooth muscle cell proliferation. Circulation (2000) 101:1982-9. doi:10.1161/01.CIR.101.16.1982

69. Garg UC, Hassid A. Nitric oxide-generating vasodilators and 8-bromo-cyclic guanosine monophosphate inhibit mitogenesis and proliferation of cultured rat vascular smooth muscle cells. J Clin Invest (1989) 85(5):1774-7. doi:10.1172/JCI114081

70. World Health Organization. World health statistics 2012. WHO Library Cataloguingin-Publications Data. (2012). Accessed from www.who.int/ gho/publications/world_health_ statistics/2012/en/

71. Fazio S, Linton MF. The inflamed plaque: cytokine production and cellular cholesterol balance in the vessel wall. Am J Cardiol (2001) 88(2A):12E$5 . \quad$ doi:10.1016/S00029149(01)01717-9

72. Singh RB, Mengi SA, Xu YJ, Arneja AS, Dhalla NS. Pathogenesis of atherosclerosis: a multifactorial process. Exp Clin Cardiol (2002) 7(1):40-53.

73. Ryoo S, Berkowitz DE, Lim HK. Endothelial arginase II and atherosclerosis. Korean $J$ Anesthesiol (2011) 61(1):3-11. doi:10.4097/kjae.2011.61.1.3

74. Kauser K, da Cunha V, Fitch R, Mallari C, Rubanyi GM. Role of endogenous nitric oxide in progression of atherosclerosis in apolipoprotein E-deficient mice. Am J Physiol Heart Circ Physiol (2000) 278:H1679-85.

75. Girerd XJ, Hirsch AT, Cooke JP, Dzau VJ, Creager MA. L-Arginine augments endothelium-dependent vasodilation in cholesterol-fed rabbits. Circ Res (1990) 67:1301-8. doi:10.1161/01.RES.67.6.1301
76. Böger RH, Bode-Böger SM, Brandes RP, Phivthongngam L, Böhme $M$, Nafe R, et al. Dietary L-arginine reduces the progression of atherosclerosis in cholesterol-fed rabbits: comparison with lovastatin. Circulation (1997) 96:1282-90. doi:10.1161/ 01.CIR.96.4.1282

77. Dhawan V, Handu SS, Nain CK, Ganguly NK. Chronic L-arginine supplementation improves endothelial cell vasoactive functions in hypercholesterolemic and atherosclerotic monkeys. Mol Cell Biochem (2005) 269(1-2):1-11. doi:10.1007/ s11010-005-1810-4

78. Raman KG, Gandley RE, Rohland J, Zenati MS, Tzeng E. Early hypercholesterolemia contributes to vasomotor dysfunction and injury associated atherogenesis that can be inhibited by nitric oxide. $J$ Vasc Surg (2011) 53:754-63. doi:10.1016/j.jvs.2010.09.038

79. Stokes KY, Dugas TR, Tang Y, Garg H, Guidry E, Bryan NS. Dietary nitrite prevents hypercholesterolemic microvascular inflammation and reverses endothelial dysfunction. Am Physiol Heart Circ Physiol (2009) 296:H1281-8. doi:10.1152/ ajpheart.01291.2008

80. Kawashima S, Yokoyama M. Dysfunction of endothelial nitric oxide synthase and atherosclerosis. Aterioscler Thromb Vasc Biol (2004) 24(6):998-1005. doi:10.1161/01.ATV.0000125114. 88079.96

81. Ohara Y, Peterson TE, Sayegh HS, Subramanian RR, Wilcox JN, Harrison DG. Dietary correction of hypercholesterolemia in the rabbit normalizes endothelial superoxide anion production. Circulation (1995) 92(4):898-903. doi:10.1161/01.CIR.92.4.898

82. Cathcart M. Regulation of superoxide anion production by NADPH oxidase in monocytes/macrophages. Arterioscler Thromb Vasc Biol (2004) 24:23-8. doi:10.1161/ 01.ATV.0000097769.47306.12

83. Dimmeler S, Haendeler J, Galle J, Zeiher AM. Oxidized low-density lipoprotein induces apoptosis of human endothelial cells by activation of CPP32-like proteases. A mechanistic clue to the 'response to injury' hypothesis. Circulation 
(1997) 95:1760-3. doi:10.1161/ 01.CIR.95.7.1760

84. Galle J, Bengen J, Schollmeyer P, Warner C. Impairment of endothelium-dependent dilation in rabbit renal arteries by oxidized lipoprotein(a). Role of oxygen-derived radicals. Circulation (1995) 92:1582-9.

85. Kugiyama K, Kerns SA, Morrisett JD, Roberts R, Henry PD. Impairment of endotheliumdependent arterial relaxation by lysolecithin in modified low-density lipoproteins. Nature (1990) 344:160-2. doi:10.1038/ 344160a0

86. Ma FX, Zhou B, Chen Z, Ren Q, Lu SH, Sawamura T, et al. Oxidized low density lipoprotein impairs endothelial progenitor cells by regulation of endothelial nitric oxide synthase. J Lipid Res (2006) 47(6):1227-37. doi:10.1194/jlr.M500507JLR200

87. Lloyd PG, Yang HT, Terjung RL. Arteriogenesis and angiogenesis in rat ischemic hindlimb: role of nitric oxide. Am J Physiol Heart Circ Physiol (2001) 281:H2528-38.

88. Pattillo CB, Fang K, Terracciano J, Kevil CG. Reperfusion of chronic tissue ischemia: nitrite and dipyridamole regulation of innate immune response. Ann N Y Acad Sci (2010) 1207:83-8. doi:10.1111/j.17496632.2010.05737.x

89. Witzenbichler B, Asahara T, Murohara T, Silver M, Spyridopoulos I, Magner $M$, et al. Vascular endothelial growth factor-C (VEGF-C/VEGF-2) promotes angiogenesis in the setting of tissue ischemia. Am J Pathol (1998) 153(2):381-91. doi:10.1016/S0002-9440(10) 65582-4

90. van Royen N, Piek JJ, Buschmann I, Hoefer I, Voskuil M, Schaper W. Stimulation of arteriogenesis; a new concept for the treatment of arterial occlusive disease. Cardiovasc Res (2001) 49:543-53. doi:10.1016/S00086363(00)00206-6

91. Yu J, deMuinck ED, Zhuang Z, Drinane M, Kauser K, Rubanyi GM, et al. Endothelial nitric oxide synthase is critical for ischemic remodeling, mural cell recruitment, and blood flow reserve. Proc Natl Acad Sci US A (2005) 102(31):109991004. doi:10.1073/pnas.050144 4102
92. Kumar D, Branch BG, Pattillo CB, Hood J, Thoma S, Simpson S, et al. Chronic sodium nitrite therapy augments ischemia-induced angiogenesis and arteriogenesis. Proc Natl Acad Sci U $S$ A (2008) 105(21):7540-5. doi:10.1073/pnas.0711480105

93. Isenberg JS, Shiva S, Gladwin MT. Thrombospondin-1-CD47 blockade and exogenous nitrite enhance ischemic tissue survival, blood flow and angiogenesis via coupled NO-cGMP pathway activation. Nitric Oxide (2009) 21(1):52-62. doi:10.1016/j.niox.2009.05.005

94. Bir SC, Pattillo CB, Pardue S, Kolluru GK, Docherty J, Goyette $\mathrm{D}$, et al. Nitrite anion stimulated ischemic arteriogenesis involving NO metabolism. Am J Physiol Heart Circ Physiol (2012) 303:H178-88. doi:10.1152/ ajpheart.01086.2010

95. Hendgen-Cotta UB, Luedike $P$, Totzeck M, Kropp M, Schicho A, Stock P, et al. Dietary nitrate supplementation improves revascularization in chronic ischemia. Circulation (2012) 126:1983-92. doi:10.1161/ CIRCULATIONAHA.112.112912

96. Petersson J, Carlström M, Schreiber O, Phillipson $M$, Christoffersson $\mathrm{G}$, Jägare $\mathrm{A}$, et al. Gastroprotective and blood pressure lowering effects of dietary nitrate are abolished by antiseptic mouthwash. Free Radic Biol Med (2009) 46(8):1068-75. doi:10.1016/ j.freeradbiomed.2009.01.011

97. Kapil V, Haydar SM, Pearl V, Lundberg JO, Weitzberg E, Ahluwalia A. Physiological role for nitrate-reducing oral bacteria in blood pressure control. Free Radic Biol Med (2013) 55:93-100. doi:10.1016/ j.freeradbiomed.2012.11.013

98. Guo JP, Panday MM, Consigny PM, Lefer AM. Mechanisms of vascular preservation by a novel NO donor following rat carotid artery intimal injury. Am J Physiol (1995) 269:H1122-31.

99. Parenti A, Morbidelli L, Cui XL, Douglas JG, Hood JD, Granger HJ, et al. Nitric oxide is an upstream signal of vascular endothelial growth factor-induced extracellular signal-regulated kinase $1 / 2$ activation in postcapillary endothelium. $J$ Biol Chem (1998) 273(7):4220-6. doi:10.1074/jbc.273.7.4220
100. Wei LH, Wu G, Morris SM, Ignarro LJ. Elevated arginase I expression in rat aortic smooth muscle cells increases cell proliferation. Proc Natl Acad Sci U S A (2001) 98(16):9260-4. doi:10.1073/pnas.161294898

101. Sparacino-Watkins CE, Lai YC, Gladwin MT. Nitratenitrite-nitric oxide pathway in pulmonary arterial hypertension therapeutics. Circulation (2012) 125(23):2824-6. doi:10.1161/ CIRCULATIONAHA.112.10782

102. Frostell C, Fratacci MD. A selective pulmonary vasodilator reversing hypoxic pulmonary vasoconstriction. Circulation (1991) 83:2038-47. doi:10.1161/01.CIR.83.6.2038

103. Zuckerbraun BS, Shiva S, Ifedigbo E, Mathier MA, Mollen KP, Rao J et al. Nitrite potently inhibits hypoxic and inflammatory pulmonary arterial hypertension and smooth muscle proliferation via xanthine oxidoreductasedependent nitric oxide generation. Circulation (2010) 121(1):98-109. doi:10.1161/ CIRCULATIONAHA.109.891077

104. Gladwin MT, Schechter AN, Kim-Shapiro DB, Patel RP, Hogg N, Shiva S, et al. The emerging biology of the nitrite anion. Nat Chem Biol (2005) 1(6):308-14. doi:10.1038/ nchembio1105-308

105. Totzeck M, Hendgen-Cotta UB, Luedike P, Berenbrink M, Klare JP, Steinhoff HJ, et al. Nitrite regulates hypoxic vasodilation via myoglobindependent nitric oxide generation. Circulation (2012) 126(3):325-34. doi:10.1161/ CIRCULATIONAHA.111.087155

106. Bloch KD, Ichinose F, Roberts JDJr., Zapol WM. Inhaled $\mathrm{NO}$ as a therapeutic agent. Cardiovasc Res (2007) 75(2):339-48. doi:10.1016/ j.cardiores.2007.04.014

107. Giaid A, Saleh D. Reduced expression of endothelial nitric oxide synthase in the lungs of patients with pulmonary hypertension. N Engl J Med (1995) 333(4):214-21. doi:10.1056/ NEJM199507273330403

108. Tuder RM, Cool CD, Geraci MW, Wang J, Abman SH, Wright L, et al. Prostacyclin synthase expression is decreased in lungs from patients with severe pulmonary hypertension. Am J Respir Crit Care Med (1999)
159(6):1925-32. doi:10.1164/ ajrccm.159.6.9804054

109. Xue C, Johns RA. Endothelial nitric oxide synthase in the lungs of patients with pulmonary hypertension. N Engl J Med (1995) 333(24):1642-4. doi:10.1056/ NEJM199512143332416

110. Hampl V, Bíbová J, Banasová A, Uhlík J, Miková D, Hnilicková $\mathrm{O}$, et al. Pulmonary vascular iNOS induction participates in the onset of chronic hypoxic pulmonary hypertension. Am J Physiol Lung Cell Mol Physiol (2006) 290(1):L11-20. doi:10.1152/ ajplung.00023.2005

111. Xu W, Kaneko FT, Zheng S, Comhair SA, Janocha AJ, Goggans $\mathrm{T}$, et al. Increased arginase II and decreased NO synthesis in endothelial cells of patients with pulmonary arterial hypertension. FASEB (2004) 18(14):1746-8.

112. Hellsten $\mathrm{Y}$, Nyberg $\mathrm{M}$, Jensen LG, Mortensen SP. Vasodilator interactions in skeletal muscle blood flow regulation. J Physiol (2012) 590:6297-305. doi:10.1113/jphysiol.2012.240762

113. Li H, Samouilov A, Liu $X$, Zweier JL. Characterization of the magnitude and kinetics of xanthine oxidasecatalyzed nitrite reduction. J Biol Chem (2001) 276:24482-9. doi:10.1074/jbc.M011648200

Conflict of Interest Statement: The authors declare that the research was conducted in the absence of any commercial or financial relationships that could be construed as a potential conflict of interest.

Received: 20 April 2013; accepted: 17 June 2013; published online: 02 July 2013.

Citation: Madigan $M$ and Zuckerbraun $B$ (2013) Therapeutic potential of the nitrite-generated NO pathway in vascular dysfunction. Front. Immunol. 4:174. doi: 10.3389/fimmu.2013.00174

This article was submitted to Frontiers in Inflammation, a specialty of Frontiers in Immunology.

Copyright (C) 2013 Madigan and Zuckerbraun. This is an open-access article distributed under the terms of the Creative Commons Attribution License, which permits use, distribution and reproduction in other forums, provided the original authors and source are credited and subject to any copyright notices concerning any third-party graphics etc. 